Article

\title{
Morphological and Molecular Characterization of Nothotylenchus medians and N. similis (Nematoda: Anguinidae) from Southern Alberta, Canada
}

\author{
Maria Munawar ${ }^{1}$, Atta Ur Rahman ${ }^{1}$, Pablo Castillo ${ }^{2}\left(\mathbb{D}\right.$ and Dmytro P. Yevtushenko ${ }^{1, *(D)}$ \\ 1 Department of Biological Sciences, University of Lethbridge, 4401 University Drive W, \\ Lethbridge, AB T1K 3M4, Canada; maria.munawar@uleth.ca (M.M.); attaur.rahman@uleth.ca (A.U.R.) \\ 2 Institute for Sustainable Agriculture (IAS), Spanish National Research Council (CSIC), Campus de Excelencia \\ Internacional Agrolimentario, ceiA3, Avenida Menendez Pidal S/N, 14004 Cordoba, Spain; p.castillo@csic.es \\ * Correspondence: dmytro.yevtushenko@uleth.ca
}

check for updates

Citation: Munawar, M.; Rahman,

A.U.; Castillo, P.; Yevtushenko, D.P. Morphological and Molecular Characterization of Nothotylenchus medians and N. similis (Nematoda: Anguinidae) from Southern Alberta, Canada. Horticulturae 2022, 8, 74. https://doi.org/10.3390/

horticulturae 8010074

Academic Editor: Harald Scherm

Received: 29 November 2021

Accepted: 7 January 2022

Published: 14 January 2022

Publisher's Note: MDPI stays neutral with regard to jurisdictional claims in published maps and institutional affiliations.

Copyright: (C) 2022 by the authors. Licensee MDPI, Basel, Switzerland. This article is an open access article distributed under the terms and conditions of the Creative Commons Attribution (CC BY) license (https:// creativecommons.org/licenses/by/ $4.0 /)$.

\begin{abstract}
The nematode family, Anguinidae, is a diverse group of polyphagous nematodes, generally known as fungal feeders or parasites of aerial plant parts. Here, we present the morphological and molecular characterization of adult females of two Nothotylenchus species, N. medians and N. similis, along with host association and geographical distribution data of the genus. Both species are recorded as new reports from Canada and designated as reference populations for future studies. Morphological or morphometrical variation was not observed in the Canadian population of N. medians and $N$. similis, in comparison with the original description. Phylogenetic analyses based on 18S and D2-D3 of $28 \mathrm{~S}$ genes placed both species within Anguinidae. Since the biology of the genus Nothotylenchus has not been rigorously characterized, the habitat and distribution information presented in this study will shed some light on the ecology of these nematodes. Notably, the detection of N. medians and $N$. similis in our nematode inventory survey indicates that considerable Nothotylenchus diversity is hidden in these soils. Consequently, increased surveys and more in-depth research are needed to explore the full diversity of anguinids inhabiting these cultivated areas.
\end{abstract}

Keywords: morphology; morphometrics; nematode management programs; new record; soil health; plant-parasitic nematodes; taxonomy

\section{Introduction}

Family Anguinidae Nicoll [1] is a diverse group of stylet-bearing nematodes generally known as fungal feeders or parasites of the aerial parts of plants [2]. The family contains about 15 genera, however only Ditylenchus Filipjev [3] and Anguina Scopoli [4] species have received significant attention due to their parasitic potential and quarantine regulations [5]. Among other genera of Anguinidae, Nothotylenchus Thorne [6] was formulated for those Ditylenchus-like species that do not possess a valvular median pharyngeal bulb $[2,6]$. Based on similarity, Nothotylenchus has been synonymized with Ditylenchus in several studies [7-9]. According to the new classification system described by Decraemer and Hunt [5], Nothotylenchus is regarded as a valid genus. Recently, Hashemi and Karegar [10] reviewed the entire genus and improved the species identification by providing a compendium of Nothotylenchus nominal species.

The genus Nothotylenchus is composed of ectoparasitic nematodes that have adapted to a diverse range of ecological niches [2,11-13]. This genus is the second-largest of the family Anguinidae after Ditylenchus, and currently comprises 41 nominal species [10,14]. These species have been reported from both agricultural and natural systems, but no significant plant damage has been associated with any Nothotylenchus spp., except for N. acris, which was reported to cause stunting and deformation of strawberry plants [15]. Biogeographically, the majority of Nothotylenchus species originate from Asian countries, 
whereas only N. acris Thorne, [6], N. acutus Khan, [16], and N. attenuatus Mulvey [17] are known to occur in Canada [17-22].

Recently, several studies reported the presence of endo- and ectoparasitic nematodes from agricultural areas of southern Alberta, Canada [23-27]. Therefore, we performed detailed samplings in cultivated areas near Barnwell in southern Alberta, with the goal of characterizing the existing biodiversity of plant-parasitic nematodes (PPNs). In our recent nematode biodiversity survey, we detected high densities ( 50-60 individuals in $250 \mathrm{~g}$ fresh soil) of two anguinid species. Given the potential economic importance of this group, the species were immediately processed for morphological and molecular characterization. Preliminary light microscopy analysis revealed the presence of lateral fields with six lateral lines, flattened lip regions, delicate stylets, and a fusiform median pharyngeal bulb without valves. Based on morphological characteristics, the species were identified as members of Nothotylenchus. Further, detailed morphometrical characterization of these populations confirmed their close resemblance to N. medians Thorne and Malek [28] and N. similis Thorne and Malek [28]. Since Nothotylenchus spp. have never been detected in southern Alberta field surveys, the present study was conducted with the main objectives of: (1) morphometrical and molecular characterization of N. medians and N. similis as newly reported species from Canada, and (2) to establish detailed molecular phylogeny, host association, and biogeography of the genus Nothotylenchus.

In practice, it is almost impossible to identify all nematode species inhabiting each soil sample. Having advanced knowledge of existing nematode biodiversity will aid researchers in rapid nematode diagnostics. Moreover, recognition and accurate identification of recovered species are important to detect nematodes that may pose a potential threat and implement effective regulatory measures.

\section{Materials and Methods}

\subsection{Isolation and Morphological Studies}

The nematode inventory survey was conducted near village of Barnwell (Alberta, Canada) to examine the wide spectrum of PPNs associated with cultivated plants. We collected several soil and root samples from different headland areas of a cultivated field, and maintained them in the cold storage $\left(4^{\circ} \mathrm{C}\right)$ at the University of Lethbridge (Alberta, Canada) until processing. Nematodes were extracted from the soil samples using the modified Cobb sieving and flotation-centrifugation method [29]. Individual anguinid taxa were collected from the mixture of soil nematodes and assigned the population numbers $42 \mathrm{~A}$ and $42 \mathrm{~B}$. For preliminary examination, fresh adults of each species were transferred to a drop of distilled water, heat relaxed, and observed under a Zeiss Axioskope 40 microscope. For morphometric studies, the nematodes were fixed, and permanent slides were prepared according to the methods of Seinhorst [30] and De Grisse [31]. Images of each specimen were acquired using a Zeiss Axioskope 40 microscope equipped with a Zeiss Axiocam 208 camera (Carl Zeiss, Jena, Germany). Measurements from the images were performed using ZEN blue 3.1 imaging software (Carl Zeiss).

\subsection{DNA Extraction, $P C R$, and Sequencing}

After preliminary microscopic examination, a single nematode of each taxon was transferred to a $0.2 \mathrm{~mL}$ PCR tube, and the DNA was extracted as described in Maria et al. [32]. Briefly, the single nematodes were crushed in $6 \mu \mathrm{L}$ Milli-Q ultrapure water using a sterile pipette tip. The tubes containing crushed nematodes were briefly spun and immediately incubated at $-80^{\circ} \mathrm{C}$ for at least $30 \mathrm{~min}$. Then, the samples were heated to $85^{\circ} \mathrm{C}$ for $2 \mathrm{~min}$, briefly spun, followed by the addition of $2 \mu \mathrm{L}$ proteinase $\mathrm{K}$ and $2 \mu \mathrm{L} 10 \times \mathrm{PCR}$ buffer. The tubes were incubated at $56^{\circ} \mathrm{C}$ for 2 to $3 \mathrm{~h}$, followed by a 10-min period at $95{ }^{\circ} \mathrm{C}$. These tubes, containing crude nematode DNA, were cooled to $4{ }^{\circ} \mathrm{C}$ and used in the subsequent PCR analyses. Three sets of DNA primers (Integrated DNA Technologies, Coralville, IA, USA) were used to amplify the 18S, 28S, and ITS1 of the ribosomal RNA (rRNA) genes. The partial $18 \mathrm{~S}$ rRNA gene was amplified with $1813 \mathrm{~F}$ and $2646 \mathrm{R}$ primers [33]. The $28 \mathrm{~S}$ rRNA 
gene was amplified using D2A and D3B primers [34] and the ITS1 gene was amplified using F194 [35] and AB28-R primers [36]. For the 18S, 28S, and ITS1 genes, the PCR conditions were as described in Holterman et al. [33], De Ley et al. [34], and Ferris et al. [35], respectively. Amplified PCR products were resolved by electrophoresis in $1 \%$ agarose gels and visualized by staining with GelRed (Biotium, Fremont, CA, USA). PCR products containing amplified DNA fragments of interest were sent to Azenta Life Sciences for DNA sequencing (South Plainfield, NJ, USA).

\subsection{Phylogenetic Analyses}

In the present study, we obtained DNA sequences for the $28 \mathrm{~S}$ rRNA (D2-D3 domains), ITS1 rRNA, and 18S rRNA genes of both Nothotylenchus populations. These sequences and additional anguinid taxa DNA sequences present in GenBank were used for phylogenetic analysis. The selection of outgroup taxa for each dataset was based on previously published studies [13,14,37]. Multiple nucleotide sequence alignments for the different genes were performed using the heuristics progressive method FFT-NS-2 algorithm of MAFFT v.7.450 [38]. The BioEdit v7.2.5 program [39] was used for sequence alignment visualization. For alignment editing, we used Gblocks v0.91b [40] on the Castresana Laboratory server (available online: http://molevol.cmima.csic.es/castresana/Gblocks_server.html (accessed on 10 November 2021) with options for a less stringent selection (minimum number of sequences for a conserved or a flanking position: $50 \%$ of the number of sequences +1 ; maximum number of contiguous non-conserved positions: 8 ; minimum length of a block: 5 ; allowed gap positions: with half)). Phylogenetic analyses were performed using Bayesian inference (BI) in MrBayes v3.1.2 [41]. The best-fit model of DNA evolution was achieved using JModelTest v2.1.7 [42] with the Akaike information criterion (AIC). Accordingly, the selected models were the general time-reversible model with invariable sites and a gammashaped distribution (GTR + I + G), and GTR + G for the D2-D3 segments of the 28S rRNA and partial 18S, respectively. The best-fit model, base frequency, proportion of invariable sites, gamma distribution shape parameters, and substitution rates in the AIC were then used in MrBayes for the phylogenetic analyses, which run with four chains for $4 \times 10^{6}$ generations in all datasets. A combined analysis of the three ribosomal genes was not undertaken due to several sequences not being available for all species. The sampling for Markov chains was carried out at intervals of 100 generations. For each analysis, two runs were conducted. After discarding $30 \%$ of the samples for burn-in and evaluating convergence, the remaining samples were retained for more in-depth analyses. The topologies were used to generate a $50 \%$ majority-rule consensus tree. On each appropriate clade, posterior probabilities (PP) were calculated. FigTree software v1.42 [43] was used for the visualization of phylogenetic trees from all analyses.

\section{Results}

\subsection{Description of Nothotylenchus medians}

Female: Body ventrally arcuate after heat relaxed, general appearance cylindroid except at extremities (Figure 1). Cuticle finely annulated, lateral field with six equidistant incisures. Lip region low, anteriorly flattened, with rounded margins, continuous with the body contours, having two or three fine annuli. Labial framework slightly sclerotized, outer margin of the basal plate extending into two to three annuli inside the body. Stylet delicate, conus $35-40 \%$ of the total stylet length (Table 1 ). Stylet knobs small, rounded, anteriorly sloping. Dorsal pharyngeal gland orifice (DGO) situated close to the stylet knobs. Median pharyngeal bulb valveless, indiscernible, and fusiform in shape. Isthmus slender, encircled with nerve ring. 

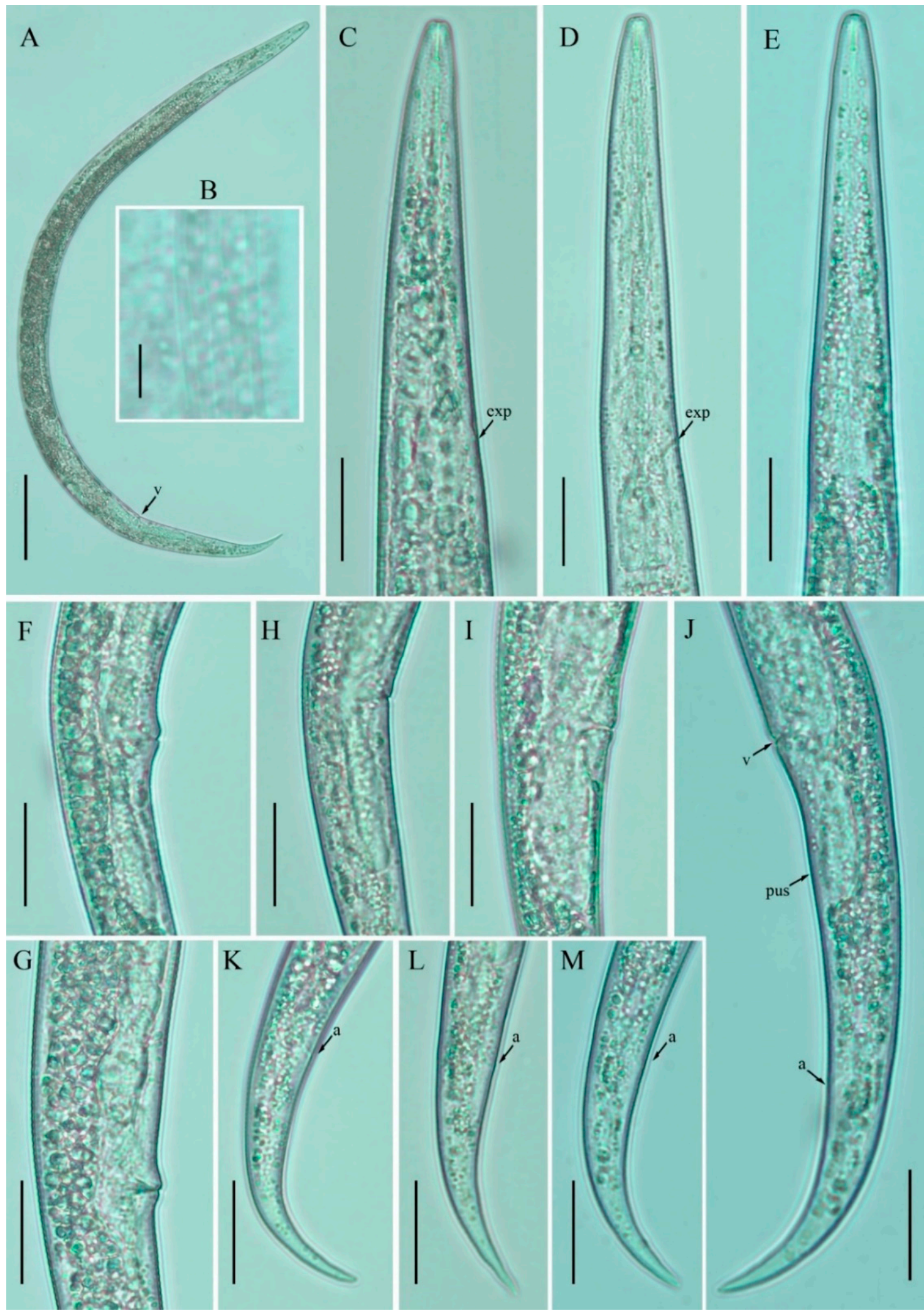

Figure 1. Photomicrographs of female Nothotylenchus medians. (A) Entire body; (B) lateral lines; (C-E) pharyngeal regions; (F-I) vulval regions; (J) posterior body to tail terminus; $(\mathbf{K}-\mathbf{M})$ tail regions. Scale bars: (A) $50 \mu \mathrm{m}$; (C-M) $20 \mu \mathrm{m}$; (B) $5 \mu \mathrm{m}$. Arrowheads: (a) anus; (exp) excretory pore; (pus) postvulval uterine sac; (v) vulva. 
Table 1. Morphometrics of female Nothotylenchus medians examined in this study and from the original and other published descriptions. All measurements are in $\mu \mathrm{m}$ and in the form: the mean \pm standard deviation and/or the range.

\begin{tabular}{|c|c|c|c|c|}
\hline Characters & This Study & $\begin{array}{l}\text { Thorne and } \\
\text { Malek [28] }\end{array}$ & \multicolumn{2}{|c|}{ Brzeski [8] } \\
\hline Locality & Canadian population & USA & Poland & Syria \\
\hline Host & Artiplex sp. & Cultivated field & \multicolumn{2}{|c|}{ Unknown } \\
\hline $\mathrm{n}$ & 16 & - & 13 & 3 \\
\hline Body length & $\begin{array}{l}598.3 \pm 48.9 \\
(536.0-740.0)\end{array}$ & 660 & $734(660-803)$ & $612-624$ \\
\hline a & $25.5 \pm 2.6(21.3-32.2)$ & 32 & $31(25-36)$ & $30-32$ \\
\hline $\mathrm{b}$ & $6.1 \pm 0.3(5.5-6.6)$ & 6.3 & $5.6(5.0-6.0)$ & $4.7-5.2$ \\
\hline c & $11.0 \pm 0.9(9.4-12.0)$ & 14 & $12.5(11.4-13.2)$ & $3.2-3.5$ \\
\hline$c^{\prime}$ & $4.6 \pm 0.4(3.8-5.3)$ & $2.8-5.8$ & $4.1(3.7-4.6)$ & $13.8(12.6-14.5)$ \\
\hline $\mathrm{MB}$ & $42.0 \pm 2.1(35.3-45.0)$ & - & $39(35-42)$ & $38-42$ \\
\hline $\mathrm{V}$ & $79.2 \pm 1.0(77.1-81.0)$ & 76 & $82(79-83)$ & - \\
\hline Lip height & $2.2 \pm 0.1(2.0-2.4)$ & - & - & - \\
\hline Lip width & $5.3 \pm 0.3(5.0-5.8)$ & - & - & - \\
\hline Stylet length & $8.1 \pm 0.6(7.3-9.5)$ & 8.0 & $7.3(6.5-8.0)$ & $6.8(6.0-7.5)$ \\
\hline Anterior end to excretory pore & $82.6 \pm 4.7(79.0-98.0)$ & - & $99(88-105)$ & $91-96$ \\
\hline Pharynx length & $98.0 \pm 5.7(88.0-116.0)$ & - & $131(111-144)$ & $124(119-130)$ \\
\hline Maximum body width & $23.6 \pm 2.4(19.3-28.0)$ & - & - & - \\
\hline Vulva body width & $21.4 \pm 1.9(18.3-25.0)$ & - & - & - \\
\hline Post-vulval uterine sac (PUS) length & $30.9 \pm 6.9(20.0-44.0)$ & - & - & - \\
\hline $\begin{array}{l}\text { Distance from } \\
\text { vulva to anus }\end{array}$ & $69.0 \pm 6.7(60.0-88.0)$ & - & - & - \\
\hline $\begin{array}{c}\text { Distance from } \\
\text { vulva to tail terminus }\end{array}$ & $\begin{array}{c}124.5 \pm 10.5 \\
(110.0-150.0)\end{array}$ & - & - & - \\
\hline Anal body width & $12.2 \pm 1.0(10.0-13.6)$ & - & - & - \\
\hline Tail length & $56.0 \pm 5.8(46.0-66.0)$ & - & $59(52-63)$ & $42-64$ \\
\hline
\end{tabular}

Abbreviations: $n$, number of specimens on which the measurements are based; a, body length/greatest body diameter; $\mathrm{b}$, body length/distance from anterior end to pharyngo-intestinal junction; $\mathrm{c}$, body length/tail length; $c^{\prime}$, tail length/tail diameter at anus; $\mathrm{MB}$, distance between the anterior end of the body and center of the median pharyngeal bulb expressed as the percentage (\%) of the pharynx length; $\mathrm{V}$, distance from the body anterior end to the vulva expressed as a percentage (\%) of the body length.

Hemizonid streak-like two to three annuli anterior to the excretory pore. Excretory pore located slightly anterior to or in range of the anterior level of the pharyngeal basal bulb. Basal pharyngeal bulb pyriform to slightly elongated, abutting intestine. Ovary outstretched with oocytes in a single row, spermatheca and crustaformeria well developed, the columnar arrangement of crustaformeria well discernable. Spermatheca elongate, vulva a transverse slit occupying less than half of the corresponding body width. Vulval lips prominent, sometimes protruding slightly. Post-vulval uterine sac pouch-like, present along the ventral body wall extending halfway to the anus. Anus a minute slit. Tail conical tapering uniformly to a finely rounded to pointed terminus.

Male: Not found.

Juveniles: Present but not studied.

Remarks: This species was first described by Thorne and Malek [28] from cultivated fields of South Dakota, USA. Brzeski [8] described two more populations of the same species from Poland and Syria. Except for the shorter pharynx length, the morphology and morphometry of the Canadian population are consistent with the original description of $N$. medians and the subsequent populations. The populations from Poland and Syria showed longer pharynx lengths (131 (111-144) $\mu \mathrm{m}$ and 124 (119-130) $\mu \mathrm{m}$, respectively, vs. $98.0(88.0-116.0) \mu \mathrm{m}$ ) compared with the Canadian population. In terms of habitat, the USA and Canadian populations of N. medians are similar; both populations were found in cultivated areas. Specifically, the Canadian population of N. medians was recovered in the rhizosphere of Artiplex sp. growing on the headland of a cultivated potato field. The 
presence of males was reported in the original description; however, we did not observe any males in the Canadian population of $N$. medians.

\subsection{Description of Nothotylenchus similis}

Female: Body C-shaped after heat relaxed, general appearance cylindroid except at extremities (Figure 2). Cuticle finely annulated, lateral field with six incisures, inner lines are weaker than the outer ones. Lip region low, anteriorly flattened, with rounded margins, continuous with the body contours having two or three fine annuli. Labial framework slightly sclerotized, outer margin of basal plate extending into two to three annuli inside the body. Stylet delicate, conus $25-30 \%$ of total stylet length (Table 2). Stylet knobs small, rounded, anteriorly sloping. Dorsal pharyngeal gland orifice (DGO) situated close to the stylet knobs. Median pharyngeal bulb valveless, fusiform in shape. Isthmus slender encircled with nerve ring. Hemizonid streak-like, two to three annuli anterior to the excretory pore. Excretory pore located at the anterior level of the pharyngeal basal bulb. Basal pharyngeal bulb cylindroid to slightly elongate abutting the intestine. Ovary outstretched with oocytes in a single row, spermatheca and crustaformeria well developed, the columnar arrangement of crustaformeria well discernable. Spermatheca elongate, irregular-shaped, vulva a transverse slit occupying less than half of the corresponding body width. Vulval lips simple, not protruding. Post-vulval uterine sac small along the ventral body wall, same size as maximum body width. Anus, a minute slit. Tail cylindrical, wider at the anal region tapering uniformly to a finely rounded to slightly pointed terminus.

Male: Not found.

Juveniles: Present but not studied.

Remarks: This species was first described by Thorne and Malek [28] from South Dakota, USA, in the rhizosphere of pasture grass. Here, we found N. similis in the rhizosphere of undetermined grasses growing on the headland of a cultivated potato field. After the formal description, this species was never reported outside its type locality. The general appearance and dimensions of the Canadian population of $N$. similis are consistent with the original description. Both the USA and Canadian populations of N. similis have been found from grasses, indicating their host preference in the family Poaceae Barnhart. The authors of the original description likely provided the measurements of holotype female, which is why we cannot determine intraspecific variation range. Consequently, we refer to the Canadian population of $N$. similis as the reference population for future studies, until topotypes of this species can be sequenced. Moreover, the male was described in the original description; however, we did not observe any male in the Canadian population of N. similis.

\subsection{Host Association and Distribution of the Species in Genus Nothotylenchus}

Genus Nothotylenchus is recognized as the second-largest genus of the family Anguinidae with 41 nominal species [2,10]. The majority of Nothotylenchus species were described decades ago, with some original descriptions in languages other than English and often difficult to access. To study the host associations and distribution of Nothotylenchus species, we collected all original descriptions from web resources and through personal communication. Through detailed literature review, we found that the food preference of Nothotylenchus species is very diverse; the species were either reported from the rhizosphere of cultivated crops (alfalfa, rice), vegetables (cabbage, eggplant, pea, potato, and sugar beet), fruit trees (apple, citrus, grapevine, mango, palm, and pear), grasses (bermudagrass, Sesleria sp., and turfgrasses), and some very unusual hosts (mosses, dead and decaying wood, insect frass, periphytons, and deciduous shrubs; Table 3). Regarding distribution, of 41 nominal species 28 were reported from Asian countries (e.g., India (14 spp.), Iran (8 spp.), Russia (1 sp.), Japan (1 sp.), and Pakistan (1 sp.)), 8 from USA, and 10 from European countries including Russian regions (Table 3). Since the feeding preference and biology of Nothotylenchus species are poorly understood, here we present a brief review of host 
associations and their place of discovery with the hope that this information will be useful to shed some light on the biology and biogeography of Nothotylenchus species.
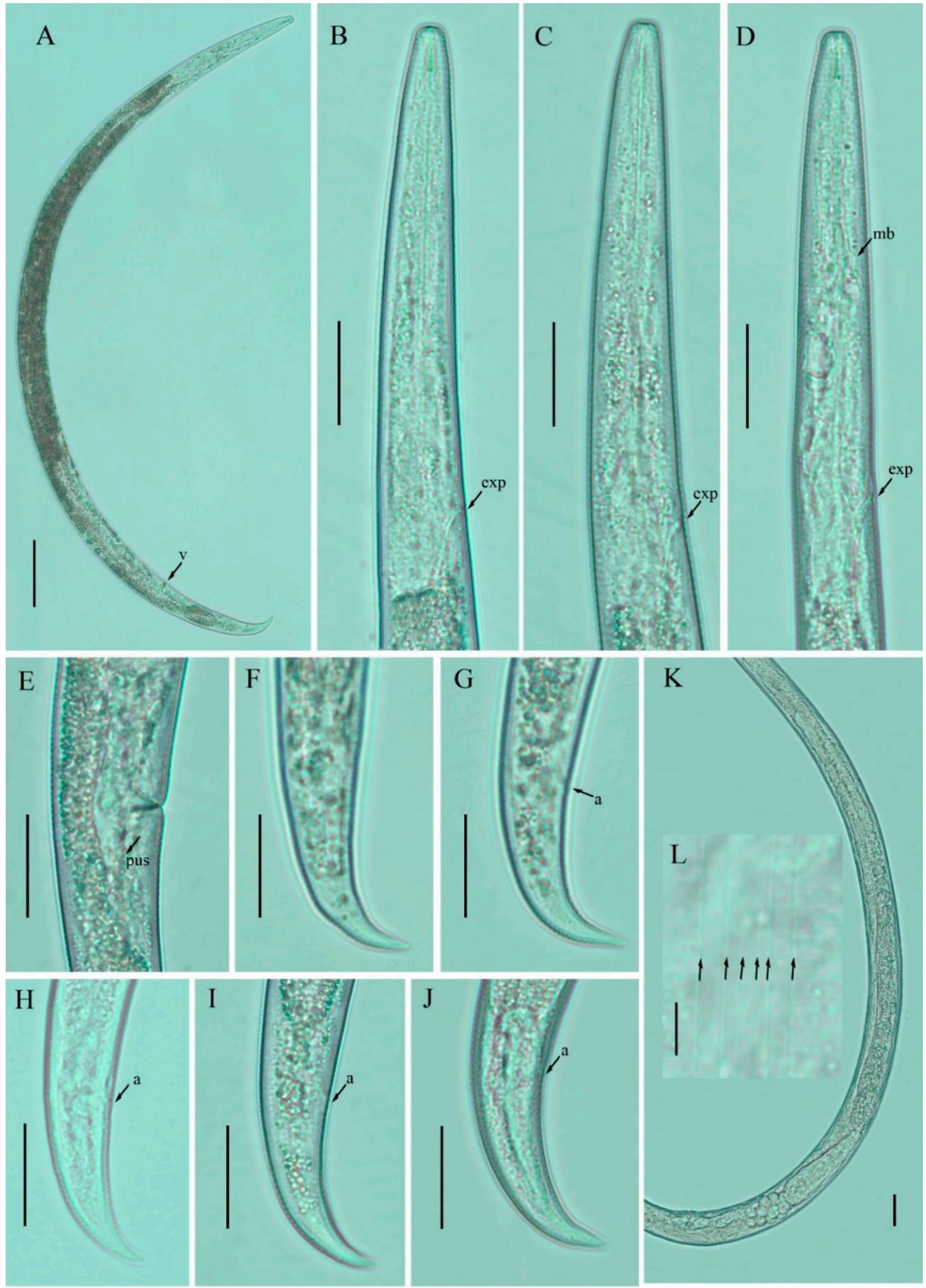

Figure 2. Photomicrographs of Nothotylenchus similis female. (A) Entire body; (B-D) pharyngeal regions; (E) vulval region; (F-J) tail regions; (K) posterior body to tail terminus; (L) lateral lines (arrowheads indicating the number of lines). Scale bars: (A) $50 \mu \mathrm{m}$; (B-K) $20 \mu \mathrm{m}$; (L) $5 \mu \mathrm{m}$. Arrowheads: (a) anus; (exp) excretory pore; (mb) median bulb; (pus) post-vulval uterine sac; (v) vulva. 
Table 2. Morphometrics of female Nothotylenchus similis from Canada and from the original description. All measurements are in $\mu \mathrm{m}$ and in the form: the mean \pm standard deviation and/or the range.

\begin{tabular}{ccc}
\hline Characters & Canadian Population & Thorne and Malek [28] \\
\hline Host & Grasses & Pasture grass \\
$\mathrm{n}$ & 16 & - \\
Body length & $783.0 \pm 48.5(693.0-885.0)$ & 900 \\
$\mathrm{a}$ & $30.0 \pm 3.4(25.0-38.4)$ & 24 \\
$\mathrm{~b}$ & $6.4 \pm 0.4(5.8-7.3)$ & 4.3 \\
$\mathrm{c}$ & $16.5 \pm 1.1(14.5-18.5)$ & 17 \\
$\mathrm{c}^{\prime}$ & $2.9 \pm 0.2(2.4-3.3)$ & - \\
MB & $43.0 \pm 2.0(38.5-46.4)$ & - \\
$\mathrm{V}$ & $84.1 \pm 0.9(82.5-85.5)$ & - \\
Lip height & $2.7 \pm 0.2(2.3-2.9)$ & - \\
Lip width & $6.9 \pm 0.5(6.4-7.5)$ & - \\
Stylet length & $9.8 \pm 0.5(8.6-10.6)$ & - \\
Pharynx length & $108.1 \pm 5.5(100.0-116.0)$ & - \\
Maximum body width & $123.1 \pm 7.0(112.0-136.0)$ & - \\
Vulva body width & $26.4 \pm 2.8(22.0-31.0)$ & - \\
Anterior end to excretory pore & $23.3 \pm 2.4(20.0-27.0)$ & - \\
Post-vulval uterine sac (PUS) length & $25.7 \pm 2.7(21.0-31.0)$ & - \\
Distance from vulva to anus & $77.0 \pm 6.1(70.0-88.0)$ & - \\
Distance from vulva to tail terminus & $124.6 \pm 6.9(115.0-137.0)$ & - \\
Anal body width & $16.2 \pm 0.9(15.0-17.6)$ & - \\
Tail length & $47.6 \pm 2.9(40.0-52.0)$ & \\
\hline
\end{tabular}

Abbreviations: $n$, number of specimens on which measurements are based; a, body length/greatest body diameter $\mathrm{b}$, body length/distance from anterior end to pharyngo-intestinal junction; $c$, body length/tail length; $\mathrm{c}^{\prime}$, tail length/tail diameter at anus; $\mathrm{MB}$, distance between the anterior end of the body and center of the median pharyngeal bulb expressed as percentage (\%) of the pharynx length; $\mathrm{V}$, distance from the body anterior end to the vulva expressed as a percentage $(\%)$ of the body length.

Table 3. Host association and distribution of nominal Nothotylenchus species.

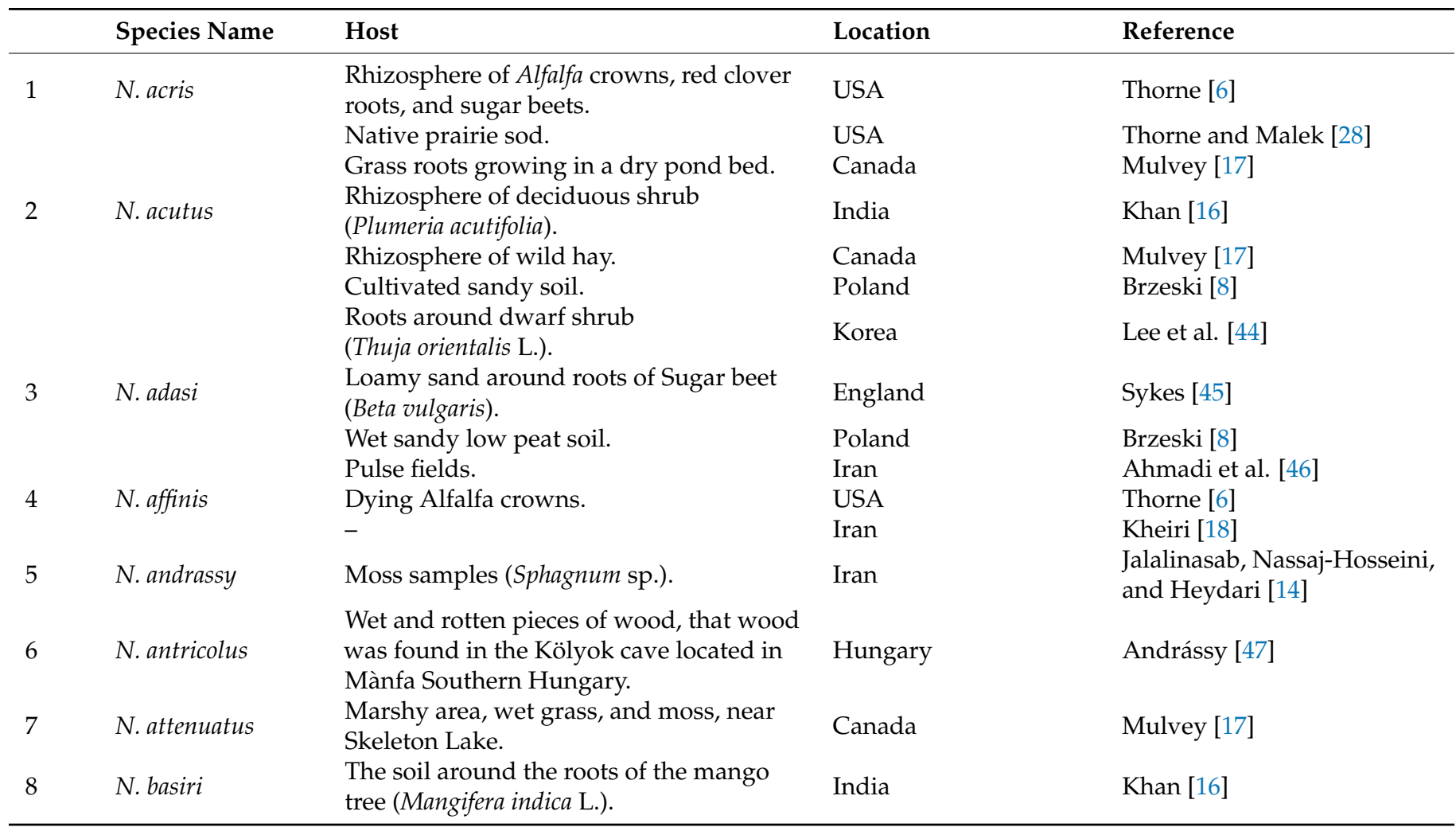


Table 3. Cont.

\begin{tabular}{|c|c|c|c|c|}
\hline & Species Name & Host & Location & Reference \\
\hline 9 & N. brzeskii & Rhizosphere of Alfafa sp. & Iran & Hashemi and Karegar [10] \\
\hline 10 & N. bhatnagari & $\begin{array}{l}\text { Rhizosphere of sorghum (Sorghum } \\
\text { vulgare). }\end{array}$ & India & Tikyani and Khera [48] \\
\hline 11 & N. bhattii & $\begin{array}{l}\text { Rhizosphere of Bermuda grass (Cynodon } \\
\text { dactylon L.). }\end{array}$ & India & $\begin{array}{l}\text { (Das and Bajaj) Hashemi and } \\
\text { Karegar }[10,21]\end{array}$ \\
\hline 12 & N. boroki & $\begin{array}{l}\text { Pine and Birchwood dead and } \\
\text { rotten material. }\end{array}$ & Central Russia & Gagarin [12] \\
\hline 13 & N. citri & Rhizosphere of Citrus sp. & India & $\begin{array}{l}\text { (Varaprasad, Khan, and Lal) } \\
\text { Siddiqi }[49,50]\end{array}$ \\
\hline 14 & N. clavatus & Roots of paddy (Oryza sativa L.). & India & $\begin{array}{l}\text { Dhanachand and } \\
\text { Gambhir [51] }\end{array}$ \\
\hline 15 & N. cylindricollis & $\begin{array}{l}\text { Soil and organic debris at the base of } \\
\text { Ananas sp. }\end{array}$ & Paraguay & Thorne [6] \\
\hline 16 & N. cylindricus & $\begin{array}{l}\text { Rhizosphere of cabbage (Brassica oleracea } \\
\text { L.) and potato (Solanuna tuberorusum L.). }\end{array}$ & India & Khan and Siddiqi [52] \\
\hline 17 & N. danubialis & $\begin{array}{l}\text { Periphyton found in the Danube River. } \\
\text { Isolated from decaying organic matter of }\end{array}$ & Hungary & Andrássy [53] \\
\hline 18 & N. drymocolus & $\begin{array}{l}\text { bark beetles (Orthotomicus suturalis; } \\
\text { Hylaster ater, H. attenuatus) residing in } \\
\text { spruce and pine trees, respectively. }\end{array}$ & Germany & Rühm [54] \\
\hline 19 & N. fotedari & $\begin{array}{l}\text { Fallow field soil, previously cultivated } \\
\text { with Mung Bean (Phaseolus aureus). } \\
\text { Rhizosphere of potato (Solanum }\end{array}$ & India & Mahajan [19] \\
\hline \multirow[t]{2}{*}{20} & N. geraerti & $\begin{array}{l}\text { tuburosum L.) and wheat (Triticum } \\
\text { aestivum L.). }\end{array}$ & Iran & Kheiri [18] \\
\hline & & - & Iran & Hashemi and Karegar [10] \\
\hline 21 & N. goldeni & Rhizosphere of apple (Pyrus malus). & Pakistan & Maqbool [20] \\
\hline \multirow[t]{4}{*}{22} & N. hexaglyphus & $\begin{array}{l}\text { Rhizosphere of potato (Solanum } \\
\text { tuberorum L.). }\end{array}$ & India & Khan and Siddiqi [52] \\
\hline & & Soil near a water canal. & Poland & Brzeski [8] \\
\hline & & Rhizosphere of palm. & Iran & Esmaeili and Heydari [22] \\
\hline & & - & Iran & Hashemi and Karegar [10] \\
\hline 23 & N. loksai & Grass rhizosphere (Sesleria sp.). & Romania & Andrássy [55] \\
\hline \multirow[t]{3}{*}{24} & N. medians & Cultivated field. & USA & Thorne and Malek [28] \\
\hline & & & Poland, Syria & Brzeski [8] \\
\hline & & Artiplex sp. & Canada & This study \\
\hline 25 & N. oryzae & Roots of paddy (Oryza sativa L.). & India & $\begin{array}{l}\text { (Mathur, Khan, and Prasad) } \\
\text { Siddiqi }[50,56]\end{array}$ \\
\hline 26 & N. persicus & $\begin{array}{l}\text { Rhizosphere of grapevine (Vitis } \\
\text { vinifera sp.). }\end{array}$ & Iran & $\begin{array}{l}\text { Esmaeili, Heydari, Castillo, } \\
\text { and Palomares-Rius [37] }\end{array}$ \\
\hline 27 & N. petilus & $\begin{array}{l}\text { Associated with Dendroctomis terehrans in } \\
\text { loblolly pine. (Pinus taeda L.). }\end{array}$ & USA & Massey [11] \\
\hline 28 & N. phoenixae & $\begin{array}{l}\text { Rhizosphere of palm trees } \\
\text { (Phoenix dactylifera L.). }\end{array}$ & Iran & $\begin{array}{l}\text { Esmaeili, Heydari, and } \\
\text { Ye [13] }\end{array}$ \\
\hline 29 & N. siddiqii & Rhizosphere of Alfalfa. & Iran & Hashemi and Karegar [10] \\
\hline \multirow[t]{2}{*}{30} & N. similis & Nature pasture grass. & USA & Thorne and Malek [28] \\
\hline & & Grasses & Canada & This study \\
\hline 31 & N. singhi & $\begin{array}{l}\text { Rhizosphere of Cabbage } \\
\text { (Brassica olearacea L.). }\end{array}$ & India & Das and Shivaswamy [57] \\
\hline 32 & N. solani & $\begin{array}{l}\text { Rhizosphere of eggplant } \\
\text { (Solanum melongena L.). }\end{array}$ & India & $\begin{array}{l}\text { (Varaprasad, Khan, and Lal) } \\
\text { Siddiqi }[49,50]\end{array}$ \\
\hline \multirow[t]{2}{*}{33} & N. taylori & $\begin{array}{l}\text { Rhizosphere of potato (Solanum tuberosum } \\
\text { L.). }\end{array}$ & India & Husain and Khan [58] \\
\hline & & Rhizosphere of Eucalyptus sp. & Sudan & Zeidan and Geraert [59] \\
\hline 34 & N. tenuis & Pinewood dead and rotten material. & Central Russia & Gagarin [12] \\
\hline 35 & N. thornei & Moss collected from the forest. & Germany & Andrássy [60] \\
\hline
\end{tabular}


Table 3. Cont.

\begin{tabular}{|c|c|c|c|c|}
\hline & Species Name & Host & Location & Reference \\
\hline 36 & N. truncatus & Rhizosphere of apple and pear trees. & Georgia & $\begin{array}{l}\text { Eliashvili and } \\
\text { Vacheishvili [61] }\end{array}$ \\
\hline 37 & N. tuberosus & $\begin{array}{l}\text { Rhizosphere of potatoes (Solanum } \\
\text { tuberosum L.). }\end{array}$ & Iran & Kheiri [18] \\
\hline 38 & N. turfus & Rhizosphere of grasses. & Japan & (Yokoo) Siddiqi $[50,62]$ \\
\hline 39 & N. uniformis & Thin branches of a large tree. & Far Eastern Russia & Truskova and Eroshenko [63] \\
\hline 40 & N. utschini & $\begin{array}{l}\text { Wild rice (Zizania latifolia Griseb) growing } \\
\text { on the bank of a water reservoir. }\end{array}$ & Central Russia & Gagarin [64] \\
\hline 41 & N. websteri & Rhizosphere of pea (Pisum satioum L.). & India & Kumar [65] \\
\hline
\end{tabular}

3.4. Molecular Characterization and Phylogenetic Relationships of Nothotylenchus medians and Nothotylenchus similis with Related Anguinid Species

We used partial 18S, 28S, and ITS1 sequencing to characterize the two anguinid species recovered in this study. The DNA sequence fragment lengths of D2-D3 of 28S and ITS1 genes for $N$. medians are $718 \mathrm{bp}$ and $743 \mathrm{bp}$, respectively, whereas the sequence fragment lengths of 18S, D2-D3 of 28S and ITS1 genes for N. similis are $549 \mathrm{bp}, 435-625 \mathrm{bp}$ and $743 \mathrm{bp}$, respectively. The newly obtained sequences were submitted to NCBI under the following accession numbers: partial 18S (OL622072 for N. similis); D2-D3 of 28S (OL622064-OL622066 for N. medians; and OL622061-OL622063 for N. similis); ITS1 (OL622071 for N. medians; OL622068-OL622070 for N. similis).

For Nothotylenchus species very limited DNA sequence-based information is available in NCBI (10 sequences only). Therefore, the $18 \mathrm{~S}$ and D2-D3 of the $28 \mathrm{~S}$ trees were constructed with the closest anguinid species sequences obtained through a BlastN search. Figure 3 presents an $18 \mathrm{~S}$ Bayesian phylogenetic tree constructed with the most highly matched anguinid species and the sequence of $N$. similis. Here, the Canadian population of N. similis grouped with N. adasi, Anguina pacificae Cid del Prado Vera and Maggenti [66], and an unidentified Ditylenchus sp. from the Netherlands. This clade is further grouped with D. gigas Vovlas, Troccoli, Palomares-Rius, De Luca, Liébanas, Landa, Subbotin, and Castillo [67], Subanguina radicicola (Greeff) Paramonov [68,69], A. agrostis (Steinbuch) Filipjev [3,70], and A. tritici. (Steinbuch) Chitwood [70,71]. The sequence identity of N. similis with aforementioned species is $96-99 \%$ with $7-23$ nucleotide difference. The other two Nothotylenchus species, namely $N$. andrassy and N. phoenixae, occupied the middle position in the tree. Another unidentified Nothotylenchus sp. from Iran [72] grouped further away from known Nothotylenchus species.

Figure 4 presents D2-D3 of 28S Bayesian phylogenetic tree constructed with the highly matched anguinid species and the sequences of the Canadian populations of both Nothotylenchus species. In this tree, N. medians and N. similis formed a clade with a few species of Ditylenchus and an identified Tylenchidae sp.1 HMM2018 from Mexico City [73]. This clade further shares a branch with $N$. persicus and N. phoenixae. The sequence identity of N. medians with related Ditylenchus and Nothotylenchus species is 83-97\% with 23-140 nucleotide difference. Whereas the sequence identity of N. similis with related Ditylenchus and Nothotylenchus species is $80-92 \%$ with 22-129 nucleotide difference. The ITS phylogenetic tree was not carried out because of the low sequence identity and poor coverage with other anguinids in the NCBI database. However, to highlight the relevance of these sequences, we searched the BlastN homology tool for the N. medians ITS sequence, which found Ditylenchus persicus and D. askenasyi to have $88-89 \%$ identity and $47-95 \%$ sequence coverage. Similarly, the BlastN search for the N. similis ITS sequence found several populations of Ditylenchus destructor to have $85 \%$ identity and $50 \%$ sequence coverage. 


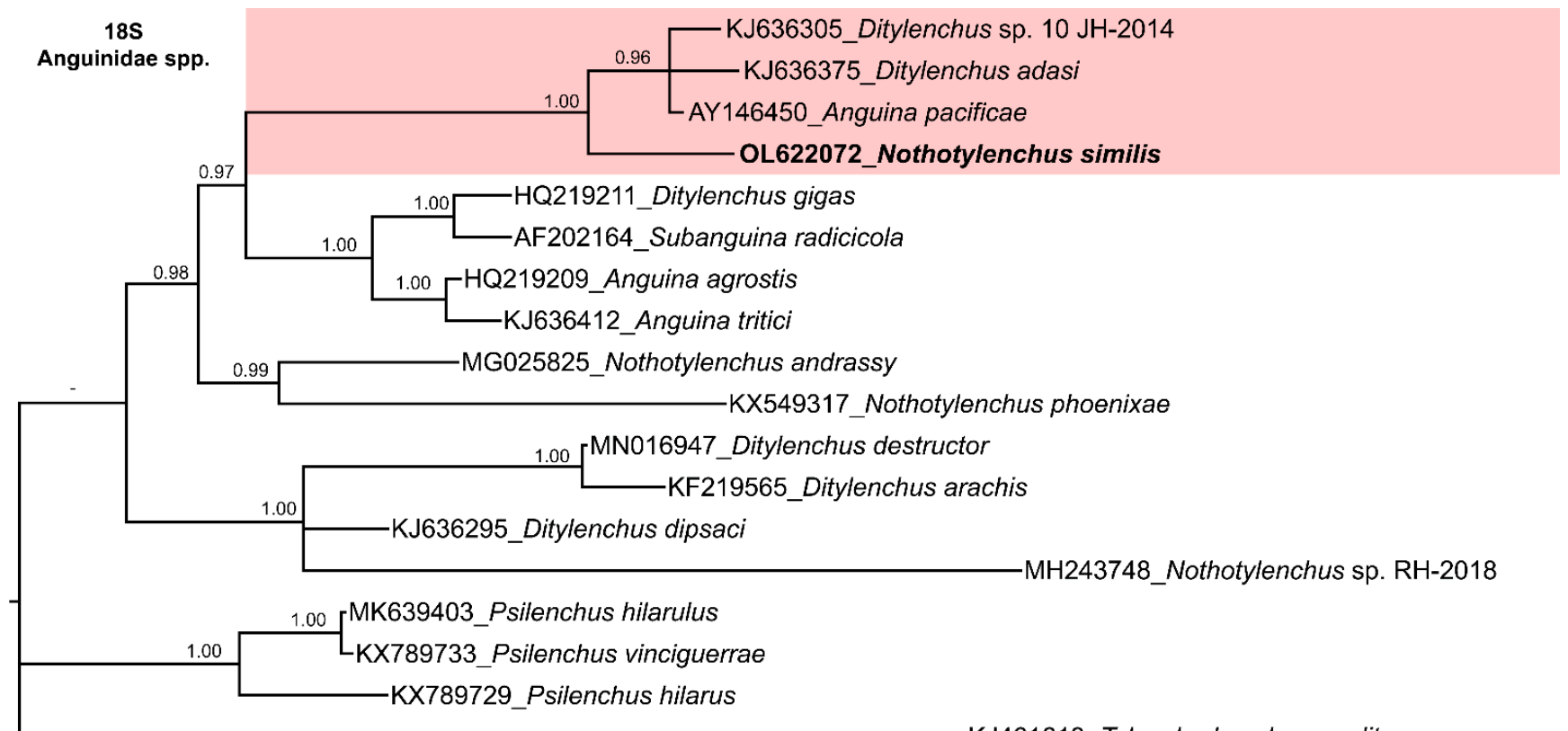

KJ461613_Tylenchorhynchus mediterraneus

0.008

Figure 3. Phylogenetic relationships of Nothotylenchus similis within Anguinidae. Bayesian 50\% majority rule consensus tree as inferred from $18 \mathrm{~S}$ rRNA sequence alignment under the general time-reversible model with invariable sites and a gamma-shaped distribution $(G T R+G)$. Posterior probabilities of more than 0.70 are given for appropriate clades. The sequences produced in this study are shown in bold, and the colored box indicates the clade association of $N$. similis.

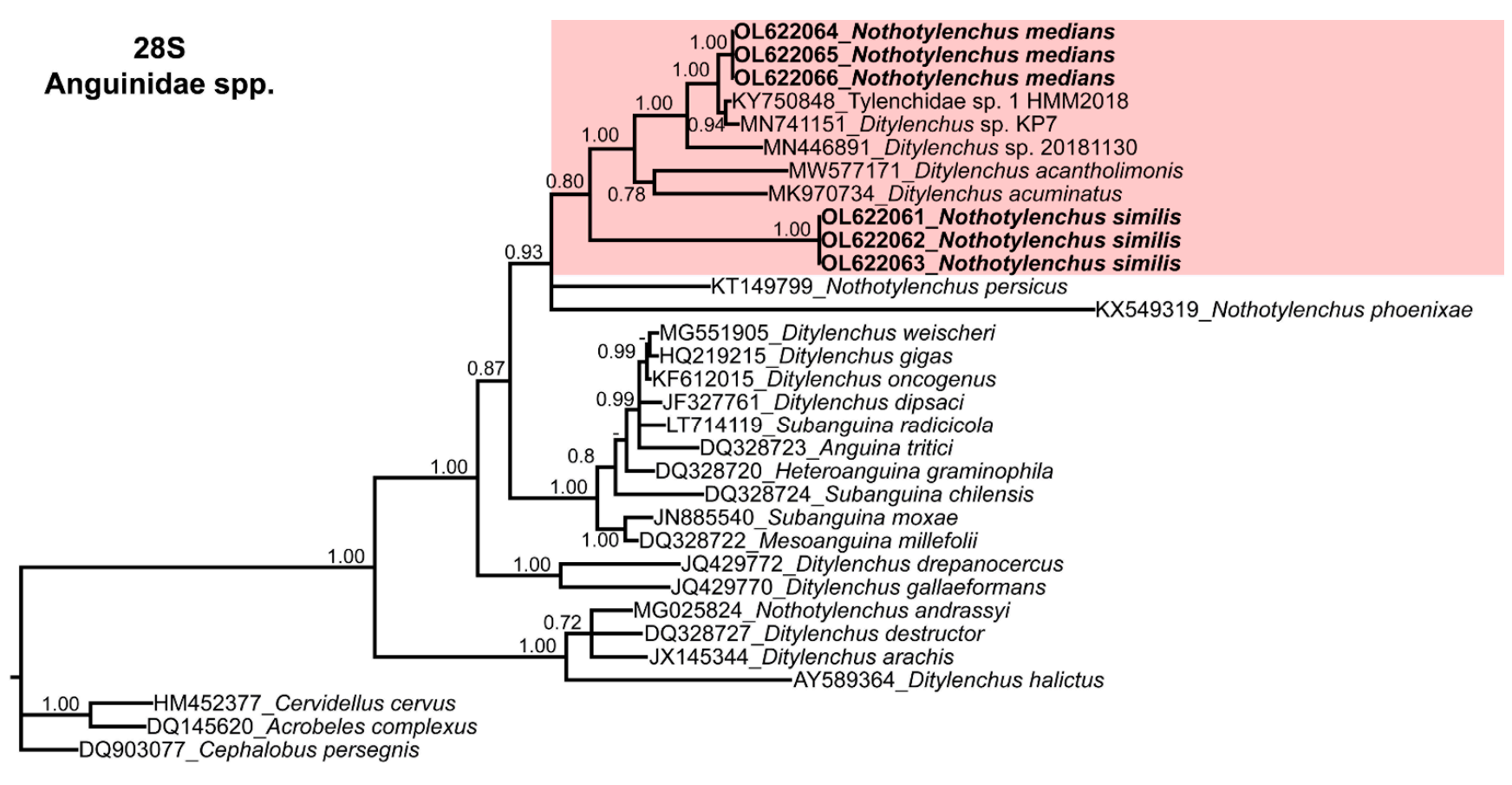

0.2

Figure 4. Phylogenetic relationships of Nothotylenchus medians and N. similis within Anguinidae. Bayesian 50\% majority rule consensus tree as inferred from D2-D3 expansion domains of the $28 \mathrm{~S}$ rRNA sequence alignment under the general time-reversible model with invariable sites and a gammashaped distribution $(G T R+I+G)$. Posterior probabilities of greater than 0.70 are given for appropriate clades. The sequences produced in this study are shown in bold, and the colored box indicates the clade association of the Canadian Nothotylenchus species detected in this study. 
The results of both phylogenetic trees support the inclusion of Nothotylenchus species in the family Anguinidae and indicate that Nothotylenchus species are not monophyletic. However, at this point, the phylogenetic relationships of Nothotylenchus species are unresolved due to the lack of enough available molecular data.

\section{Discussion}

Understanding the existing biodiversity of PPNs is important because of their wide range of survival adaptations and dispersal routes [24,25,27]. In our prior nematode inventory surveys, Nothotylenchus species were never detected because some field areas (headland vegetation) had not been surveyed for nematode infestation. The detection of Nothotylenchus species in the headland areas of cultivated fields indicated that weeds or field vegetation on headlands are potential reservoirs and sources of harboring PPNs.

Our genus-wide literature review highlighted that Nothotylenchus species occur in a wide variety of habitats, mostly in the rhizospheres of plants and less frequently in mosses, periphyton, and decaying wood materials, indicating that the species in this genus are quite generalized and could survive in a multitude of environments and plant hosts. Unlike the closest relative, Ditylenchus, Nothotylenchus species do not have a cosmopolitan distribution; so far, only N. acris, N. acutus, N. affinis, N. adasi, N. hexaglyphus, N. medians, and $N$. similis have been found outside of their type locality $[8,10,17,18,28]$.

The majority of Nothotylenchus species are amphimictic (i.e., male and female are required for reproduction); however, there are 8 species (N. antricolus, N. attenuatus, N. clavatus, N. hexaglyphus, N. loksai, N. thornei, N. truncatus, and N. tuberosus) that were described without males. Among these species, some were reported with empty spermathecae, and some with or without sperms. It appears that Nothotylenchus males are important in reproduction; however, during our survey, no Nothotylenchus males were encountered in the examined collections, suggesting that they are not very common for these species.

Integrative taxonomic identification covering morphological and molecular aspects of a species offers adequate data to properly assign species identification to the relevant taxa [74]. Regarding Nothotylenchus, only recently described species were characterized with molecular markers. Of 41 nominal species, the molecular characterization is only available for $N$. andrassy, $N$. persicus, and N. phoenixae. The lack of molecular information prohibited us from constructing a more complete and conclusive phylogenetic relationship of Nothotylenchus species. Our findings are in line with several researchers who reported that insufficient molecular data is the limiting factor in studying Nothotylenchus species' relationships with each other and with related anguinids $[13,14,37]$. Based on the available phylogeny results, it may be concluded that Nothotylenchus species are composed of divergent lineages. This has been reflected in their feeding habits as well, e.g., N. antricolus was found in the rotten pieces of decaying wood in a cave [47], N. boroki and N. tenuis, in the deadwood materials of pine and Birch [12], and N. drymocolus and N. petilus, in insect frass [11,54]. Considering this, we anticipate that a genus-wide phylogenetic analysis would shed more light on the ecology and biology of these nematodes.

Taxonomic records presently list N. acris, N. acutus, and N. attenuatus from Canada, indicating there are gaps in our knowledge of this complex group that ought to be studied in more detail [17]. The discovery of N. medians and N. similis from cultivated areas in southern Alberta illustrate that considerable anguinid diversity is hidden within these soils. Consequently, increased surveys and more in-depth research are needed in order to further our understanding of the full diversity of anguinids inhabiting Canada's cultivated soils.

\section{Conclusions}

Our study aimed to update and summarize the current state of knowledge regarding the distribution and host associations of Nothotylenchus species. Understanding the occurrence and distribution of plant-parasitic nematodes is crucial-some are economical pests, and some are important to soil function. In the present study, we describe two anguinid species, namely $N$. medians and $N$. similis, as the first such records from Canada. 
The presence of Nothotylenchus species in our cultivated areas does not indicate that yield losses are inevitable - not all nematode species are destined to harm or significantly reduce crop production. However, we assert that the recognition and accurate identification of detected species are important to assess if these nematodes can pose any potential threat in the future and to predict if these species may eventually require appropriate control strategies and regulatory measures. Importantly, we found that the headland areas of cultivated fields are the main sources of nematode infestation. Finally, our discovery of PPNs hitherto unreported from a cultivated region indicates that exploration of the full diversity of inhabiting anguinids warrants increased research attention.

Accession numbers obtained in this study: Nothotylenchus medians; D2-D3 of 28S, OL622064-OL622066 and ITS1, OL622071. Nothotylenchus similis: partial 18S, OL622072; D2-D3 of 28S, OL622061-OL622063; ITS1 OL622068-OL622070.

Author Contributions: Conceptualization, M.M. and D.P.Y.; methodology, M.M., P.C. and D.P.Y.; software, M.M. and P.C.; validation, M.M., P.C. and D.P.Y.; formal analysis, M.M., P.C. and D.P.Y.; investigation, M.M., A.U.R. and D.P.Y.; resources, D.P.Y.; data curation, M.M.; writing—original draft preparation, M.M., P.C. and D.P.Y.; writing—review and editing, M.M., P.C. and D.P.Y.; visualization, M.M. and P.C.; supervision, D.P.Y.; project administration, D.P.Y.; funding acquisition, D.P.Y. All authors have read and agreed to the published version of the manuscript.

Funding: This work was supported by the Potato Early Dying Complex project funded by the University of Lethbridge Research Operating Fund, and the Canadian Potato Early Dying Network project funded by the Canadian Agri-Science Cluster for Horticulture 3 grant to D.P.Y., in collaboration with the Potato Growers of Alberta (Taber, AB, Canada), McCain Foods Canada Ltd. (Chin, AB, Canada), Cavendish Farms Corp. (Lethbridge, AB, Canada), and Lamb Weston Inc (Purple Springs, $\mathrm{AB}$, Canada).

Institutional Review Board Statement: Not applicable.

Informed Consent Statement: Not applicable.

Data Availability Statement: Not applicable.

Acknowledgments: We thank potato growers in Alberta, Canada, for providing access to their fields. We cordially thank Akbar Karegar from Shiraz University, Iran, for providing electronic copies of research articles. We thank Nick Schimpf from the University of Lethbridge Alberta, for valuable help in the translation of German language nematode descriptions. We also thank Carolina Cantalapiedra-Navarrete (Institute for Sustainable Agriculture [IAS], CSIC, Córdoba, Spain), for the excellent technical assistance in molecular analysis.

Conflicts of Interest: The authors declare no conflict of interest.

\section{References}

1. Nicoll, W.; Vermes, V.I. Rhabditida. Anguinidae. Zool. Rec. 1935, 72, 105.

2. Siddiqi, M. Order Tylenchida. In Tylenchida: Parasites of Plants and Insects, 2nd ed.; CABI: Wallingford, UK, $2000 ;$ pp. 86-121.

3. Filipjev, I. On the classification of the Tylenchinae. Proc. Helminthol. Soc. Wash. 1936, 3, 80-82.

4. Scopoli, G.A. Introductio Ad Historiam Naturalem Sistens Genera Lapidum, Plantarum et Animalium: Hactenus Detecta, Caracteribus Essentialibus Donata, in Tribus Divisa, Subinde Ad Leges Naturae; Apud Wolfgangum Gerle: Prague, Czech Republic, 1777.

5. Decraemer, W.; Hunt, D.J. Structure and Classification, 2nd ed.; CABI Publishing: Wallingford, UK, 2013 ; pp. 3-32.

6. Thorne, G. Some nematodes of the family Tylenchidae which do not possess a valvular median esophageal bulb. Great Basin Nat. 1941, 2, 37-85.

7. Fortuner, R.; Maggenti, A.R. A reappraisal of Tylenchina (Nemata). 4. The family Anguinidae Nicoll, 1935 (1926). Rev. Nématol. 1987, 10, 163-176.

8. Brzeski, M.W. Review of the genus Ditylenchus Filipjev, 1936 (Nematoda: Anguinidae). Rev. Nématol. 1991, 14, 9-59.

9. Sturhan, D.; Brzeski, M.W. Stem and bulb nematodes, Ditylenchus spp. In Manual of Agricultural Nematology; CRC Press: Boca Raton, FL, USA, 1991; pp. 423-464.

10. Hashemi, K.; Karegar, A. New and known species of Nothotylenchus Thorne, 1941 (Nematoda: Anguinidae) from Iran with an updated list of species. Zootaxa 2020, 4729, 482-500. [CrossRef]

11. Massey, C.L. Biology and Taxonomy of Nematode Parasites and Associates of Bark Beetles in the United States; Forest Service, US Department of Agriculture: Washington, DC, USA, 1974. 
12. Gagarin, V. Nematode fauna in rotten wood of birch, aspen, and pine in Borok (Yaroslavl'district, Central Russia). Zool. Zhurnal 1999, 78, 146-157.

13. Esmaeili, M.; Heydari, R.; Ye, W. Description of a new anguinid nematode, Nothotylenchus phoenixae n. sp.(Nematoda: Anguinidae) associated with palm date trees and its phylogenetic relations within the family Anguinidae. J. Nematol. 2017, 49, 268-275. [CrossRef]

14. Jalalinasab, P.; Hosseini, M.N.; Heydari, R. Nothotylenchus andrassy n. sp.(Nematoda: Anguinidae) from Northern Iran. J. Nematol. 2018, 50, 219-228. [CrossRef]

15. Kim, D.-G.; Kim, S.-H.; Lee, J.-H. Ditylenchus acris (Thorne, 1941) Fortuner and Maggenti 1987, A New Strawberry Nematode in Korea. Plant Pathol. J. 2005, 21, 83-85. [CrossRef]

16. KHAN, S.H. Nothotylenchus acutus n. sp. and N. basiri n. sp.(Nematoda: Nothotylenchinae) from North India. Proc. Helminthol. Soc. Wash. 1965, 32, 90-93.

17. Mulvey, R. Nematodes of the family Neotylenchidae (Tylenchida: Nematoda) from the Canadian high Arctic. Can. J. Zool. 1969, 47, 1261-1268. [CrossRef]

18. Kheiri, A. Two new species of Nothotylenchus Thorne, 1941 from Iran and a redescription of N. affinis Thorne, 1941 (Nematoda, Neotylenchidae) with a key to the species of the genus. Nematologica 1971, 16, 591-600. [CrossRef]

19. Mahajan, R. Scutellonema petersi n. sp. and Nothotylenchus fotedari n. sp., two new nematodes from India. Riv. Parassitol. 1977, 38, 334-337.

20. Maqbool, M. Three new species of the super family Neotylenchoidea (Nematoda: Tylenchida) from Pakistan. J. Nematol. 1982, 14, 317-323.

21. Das, D.; Bajaj, H.K. New and known species of Ditylenchus Filipjev, 1936 from Haryana, India. Indian J. Nematol. 2005, 35, 11-23.

22. Esmaeili, M.; Heydari, R. New record of three species of Ditylenchus Filipjev, 1936 (Nematoda: Anguinidae), with a key to the species reported from Iran. J. Crop Prot. 2016, 5, 565-579. [CrossRef]

23. Forge, T.A.; Larney, F.J.; Kawchuk, L.M.; Pearson, D.C.; Koch, C.; Blackshaw, R.E. Crop rotation effects on Pratylenchus neglectus populations in the root zone of irrigated potatoes in southern Alberta. Can. J. Plant Pathol. 2015, 37, 363-368. [CrossRef]

24. Munawar, M.; Yevtushenko, D.P.; Palomares-Rius, J.E.E.; Castillo, P. Species diversity of pin nematodes (Paratylenchus spp.) from potato growing regions of southern Alberta, Canada. Plants 2021, 10, 188. [CrossRef]

25. Munawar, M.; Yevtushenko, D.P.; Castillo, P. Integrative taxonomy, distribution, and host associations of Geocenamus brevidens and Quinisulcius capitatus from southern Alberta, Canada. J. Nematol. 2021, 53, e2021-15. [CrossRef]

26. Munawar, M.; Yevtushenko, D.P.; Castillo, P. Overview of the Genus Boleodorus and First Reports of Boleodorus thylactus and B. volutus from Southern Alberta, Canada. Animals 2021, 11, 1760. [CrossRef]

27. Munawar, M.; Yevtushenko, D.P.; Castillo, P. First Report of Three Tylenchidae Taxa from Southern Alberta, Canada. Horticulturae 2021, 7, 449. [CrossRef]

28. Thorne, G.; Malek, R.B. Nematodes of the northern Great Plains. Part I. Tylenchida (Nemata: Secernentea). Tech. Bull. S. Dakota Agric. Exp. Stn 1968, 1-111. Available online: https: / / openprairie.sdstate.edu/cgi/viewcontent.cgi? article $=1001 \&$ context= agexperimentsta_tb (accessed on 28 November 2021).

29. Jenkins, W. A rapid centrifugal-flotation technique for separating nematodes from soil. Plant Dis. Report. 1964, $48,692$.

30. Seinhorst, J. A rapid method for the transfer of nematodes from fixative to anhydrous glycerin. Nematologica 1959, 4, 67-69. [CrossRef]

31. De Grisse, A.T. Redescription ou modifications de quelques technique utilis [a] es dan l'etude des $\mathrm{n}$ [a] ematodes phytoparasitaires. Meded. Rijksfakulteit Landbowwetenschappen Gent. 1969, 34, 351-369.

32. Maria, M.; Powers, T.; Tian, Z.; Zheng, J. Description and distribution of three criconematids nematodes from Hangzhou, Zhejiang Province, China. J. Nematol. 2018, 50, 183-206.

33. Holterman, M.; van der Wurff, A.; van den Elsen, S.; van Megen, H.; Bongers, T.; Holovachov, O.; Bakker, J.; Helder, J. Phylumwide analysis of SSU rDNA reveals deep phylogenetic relationships among nematodes and accelerated evolution toward crown clades. Mol. Biol. Evol. 2006, 23, 1792-1800. [CrossRef]

34. De Ley, P.; Felix, M.-A.; Frisse, L.; Nadler, S.; Sternberg, P.; Thomas, W.K. Molecular and morphological characterisation of two reproductively isolated species with mirror-image anatomy (Nematoda: Cephalobidae). Nematology 1999, 1, 591-612. [CrossRef]

35. Ferris, V.; Ferris, J.; Faghihi, J. Variation in spacer ribosomal DNA in some cyst-forming species of plant parasitic nematodes. Fundam. Appl. Nematol. 1993, 16, 177-184.

36. Curran, J.; Driver, F.; Ballard, J.; Milner, R. Phylogeny of Metarhizium: Analysis of ribosomal DNA sequence data. Mycol. Res. 1994, 98, 547-552. [CrossRef]

37. Esmaeli, M.; Heydari, R.; Castillo, P.; Palomares-Rius, J.E. Nothotylenchus persicus n. sp.(Nematoda: Anguinidae) from Kermanshah province, Iran. Nematology 2016, 18, 29-37. [CrossRef]

38. Katoh, K.; Rozewicki, J.; Yamada, K.D. MAFFT online service: Multiple sequence alignment, interactive sequence choice and visualization. Brief. Bioinform. 2019, 20, 1160-1166. [CrossRef] [PubMed]

39. Hall, T. BioEdit: A User-Friendly Biological Sequence Alignment Editor and Analysis Program for Windows 95/98/NT. Nucleic Acids Symp. Ser. 1999, 41, 95-98. 
40. Castresana, J. Selection of conserved blocks from multiple alignments for their use in phylogenetic analysis. Mol. Biol. Evol. 2000, 17, 540-552. [CrossRef]

41. Ronquist, F.; Huelsenbeck, J.P. MrBayes 3: Bayesian phylogenetic inference under mixed models. Bioinformatics 2003, 19, 1572-1574. [CrossRef]

42. Darriba, D.; Taboada, G.L.; Doallo, R.; Posada, D. jModelTest 2: More models, new heuristics and parallel computing. Nat. Methods 2012, 9, 772. [CrossRef]

43. Rambaut, A. FigTree v1. 4.2, a Graphical Viewer of Phylogenetic Trees. 2014. Java. 2018. Available online: https://github.com/ rambaut/figtree (accessed on 10 November 2021).

44. Lee, J.-H.; Park, S.-J.; Choi, S.-Y. An Unrecorded Species Ditylenchus myceliophagus and Descripton of Ditylenchus acutus (Nematoda: Anguinidae) from Korea. Korean J. Appl. Entomol. 2010, 49, 171-174. [CrossRef]

45. Sykes, G. A new species of Nothotylenchus (Nematoda: Neotylenchoidea) from England. Syst. Parasitol. 1980, 1, 237-239. [CrossRef]

46. Ahmadi, S.; Mahdikhani Moghaddam, E.; Baghaee Davari, S. Identification of plant parasitic nematode collected from pulse fields in Northern Khorasan province. Iran. J. Pulses Res. 2014, 5, 111-118.

47. Andrássy, I. Zur taxonomie der Neotylenchiden. Nematologica 1961, 6, 25-36. [CrossRef]

48. Tikyani, M.; Khera, S. Nothotylenchus bhatnagari n. sp. from the rhizosphere of great millet (Sorghum vulgare Pers.). Zool. Anz. 1969, 182, 87-91.

49. Varaprasad, K.; Khan, E.; Lal, M. Paurodontus solani sp. n. and P. citri sp. n.(Nematoda: Neotylenchoidea) with a key to the species of Paurodontus Thorne, 1941. Indian J. Nematol. 1980, 10, 182-188.

50. Siddiqi, M. Tylenchida: Parasites of Plants and insects—Commonwealth Agricultural Bureaux; CABI: Slough, UK, $1986 ;$ p. 645.

51. Dhanachand, C.; Gambhir, R. One new and two known species of Tylenchida from Manipur, India. Curr. Nematol. 1991, 2, 33-38.

52. Khan, A.M.; Siddiqi, M.R. Three new species of Nothotylenchus (Nematoda: Neotylenchidae) from North India. Nematologica 1968, 14, 369-376.

53. Andrássy, I. Beiträge zur Kenntnis der Freilebenden Nematoden Chinas; Annales Historico-Naturales Musei Nationalis Hungarici; 1960; pp. 202-216.

54. Rühm, W. Die Nematoden der Ipiden. Parasitologische Schriftenreihe; Fischer: Jena, Germany, 1956.

55. Andrássy, I. Freilebende nematoden aus Rumänien. Sect. Biol. 1959, 2, 3-27.

56. Mathur, V.; Khan, E.; Prasad, S. Boleodoroides oryzae n. g., n. sp.(Nematoda: Boleodorinae) from Bihar, India. Nematologica 1966, 12, 448-452. [CrossRef]

57. Das, V.; Shivaswamy, V. Paurodontus brassicae n. sp. and Nothotylenchus singhi n. sp. from South India. Proc. Indian Acad. Parasitol. 1980, 1, 62-65.

58. Husain, S.; Khan, A. Three new species of neotylenchid nematodes from north India. Indian J. Nematol. 1974, 4, 81-87.

59. Zeidan, A.; Geraert, E. The Genus Ditylenchus Filipjev, 1936 in Sudan (Nematoda: Tylenchida). Afro-Asian J. Nematol. 1991, 1, 5-14.

60. Andrássy, I. Erd- und Süsswassernematoden aus Bulgarien. Acta Zool. Acad. Sci. Hung. 1958, 4, 1-88.

61. Eliashvili, T.; Vacheishvili, L. New species of the nematode Nothotylenchus truncatus sp. nov.(Nematoda: Tylenchida) from Eastern Georgia. Soobshcheniia Akad. Nauk. Gruz. SSR. Bull. Acad. Sci. Georgian SSR 1980, 98, 177-180.

62. Yokoo, T. Nematological studies on the yellow patch of green grass of the golf link: II. On the nemic-fauna in the green grass of International Golf Link of Isahaya, Nagasaki Prefecture, with descriptions on new species of Neotylenchus (Nematoda: Neotylenchidae). Agric. Bull. Saga Univ. 1968, 26, 9-19.

63. Truskova, G.; Eroshenko, A. The nematode fauna of herbaceous and ligneous plants in the pine plantations of the Primor'yal. Tr. Biol. Inst. Novaya Seriya 1977, 47, 35-49.

64. Gagarin, V. Two new species of the genus Nothotylenchus (Nothotylenchidae: Nematoda) and description of males of Tylocephalus auriculatus and Chronogaster typicus. Tr. Gelan 1974, 24, 30-35.

65. Kumar, P. Nothotylenchus websteri n. sp.(Nematoda: Neotylenchoidea) from Lucknow. Indian J. Parasitol. 1983, 7, $105-107$.

66. Vera, I.C.D.P.; Maggenti, A.R. A new gall-forming species of Anguina Scopoli, 1777 (Nemata: Anguinidae) on bluegrass, Poa annua L., from the coast of California. J. Nematol. 1984, 16, 386-392.

67. Vovlas, N.; Troccoli, A.; Palomares-Rius, J.E.; De Luca, F.; Liébanas, G.; Landa, B.B.; Subbotin, S.A.; Castillo, P. Ditylenchus gigas n sp. parasitizing broad bean: A new stem nematode singled out from the Ditylenchus dipsaci species complex using a polyphasic approach with molecular phylogeny. Plant Pathol. 2011, 60, 762-775. [CrossRef]

68. Greeff, R. Über Nematoden in Wurzelanschwellungen (Gallen) verschiedener Pflanzen. Sitz. Der Ges. Zür Beförderung Der Gesamten Nat. Zu Marburg 1872, 11, 172-174.

69. Paramanov, A. A Critical Review of the Suborder Tylenchina (Filipjev, 1934)(Nematoda: Secernentea). Akad. Nauk. SSSR Tr. Gel'mint. Lab. 1967, 18, 78-101.

70. Steinbuch, J.G. Das Grasaelchen, Vibrio Agrostis; Der Naturforscher: Halle, Germany, 1799.

71. Chitwood, B. Nomenclatorial notes, I. Proc. Helminthol. Soc. Wash. 1935, 2, 51-54.

72. Heydari, R.; Esmaeili, M. A New Anguinid Nematode from Iran. Available online: https://www.ncbi.nlm.nih.gov/nucleotide/ MH243748.1?report=genbank\&log\$=nucltop\&blast_rank=1\&RID=U7MNHB1D01R (accessed on 28 November 2021) 
73. Mejia-Madrid, H.H. Soil Nematode Abundance and Diversity from Four Vegetation Types in Central Mexico. Available online: https:/ / www.ncbi.nlm.nih.gov/nucleotide/KY750848.1?report=genbank\&log $\$=$ nucltop\&blast_rank=1\&RID=U7MR1 6XR01R (accessed on 28 November 2021).

74. Subbotin, S.A.; Vovlas, N.; Crozzoli, R.; Sturhan, D.; Lamberti, F.; Moens, M.; Baldwin, J.G. Phylogeny of Criconematina Siddiqi, 1980 (Nematoda: Tylenchida) based on morphology and D2-D3 expansion segments of the 28S-rRNA gene sequences with application of a secondary structure model. Nematology 2005, 7, 927-944. 